\title{
Activists now urge caution on approval of new AIDS drug
}

Washington. In an apparent reversal of roles, scientists advising the Food and Drug Administration (FDA) have given the go-ahead for the use of the drug ddC on its own as a treatment for HIV - despite objections from AIDS activists that the potential value of the drug has yet to be demonstrated.

The FDA's Antiviral Drug Advisory Committee decided at a meeting in Rockville, Maryland, last week that $\mathrm{ddC}$, which is produced by Hoffman-LaRoche, should be given FDA approval as a treatment for HIV patients who do not respond to AZT, or suffer side-effects from its use.

The decision was based on a trial conducted by the Community Program for Clinical Research on AIDS (CPCRA), which compared the drug's efficacy with that of the approved Bristol-Myers alternative, ddI.

But Gregg Gonsalves of the Treatment Action Group (TAG) in New York - one of several groups that opposed the application - told the meeting that approval of $\mathrm{ddC}$ could "open the floodgates for drugs bearing only the merest hint of clinical usefulness".

The panel's decision, and the objections of the activist groups, could mark a turning point in the politics of AIDS drug approval. In the past, many powerful activist groups have pushed for the early arrival of drugs onto the market, however tentative the evidence of their effectiveness, while the scientific establishment fought for restraint.

But faced with a number of disappointing trials, such as the European Concorde trial of the AIDS drug AZT (see Nature $\mathbf{3 6 2}$, $483 ; 1993$ ), groups such as TAG and the California-based Project Inform now want the FDA and the drug companies to do more to prove the efficacy of a drug before new treatments go on the market.

Deborah Cotton, a clinical researcher at Massachusetts General Hospital in Boston and an influential figure on the 13-strong committee, denies that the meeting's outcome means that divisions between scientists and activists are sharpening. "We are both trying to be pragmatic", she says.

The CPCRA study showed that patients who took ddC tended to survive longer than those taking ddI. "That probably was the key study that influenced the decision," says

\section{Correction: LHC costs}

The Large Hadron Collider proposed for the European Laboratory for Particle Physics (CERN) in Geneva is predicted to cost about SFr2 billion (less than $£ 1$ billion) and not $£ 7$ billion (Nature 365, 96; 9 September 1993). This compares with current estimates of $\$ 11$ billion for the cost of the US Superconducting Super Collider.
David Feigal, director of the FDA's antiviral drugs division.

But AIDS activists at the meeting argued that the trial in fact showed broadly similar results for the two drugs. And they say that, despite the fact that ddI has already been given FDA approval, there is still insufficient evidence of the efficacy of either drug.

Cotton, who voted for the approval of ddC, says that she understands the activists' point of view. "But I felt the sponsor had demonstrated ddC's equivalence to ddI. While you may question whether either therapy is useful, I felt the trial design had been agreed to, and the company had done what it said it would do."

While giving their approval to the use of ddC on its own, the committee also advised the withdrawal of an accelerated approval process initiated last year for its use in combination with AZT. This was based on a trial by the National Institutes of Health's AIDS Clinical Trials Group which compared ddC. AZT and a combination of both.

The trial demonstrated possible benefits from combination therapy for some groups of patients. But, after hearing that it showed no overall improvement in survival time, the panel recommended that the accelerated approval be withdrawn.

The FDA's accelerated approval process involves special steps, such as the pre-vetting of all advertising, to ensure that the release of a drug onto the market is carefully controlled before its efficacy has been fully proved. Some members of the advisory committee are uneasy about the process

The panel has now taken the opportunity to show that its approval can be withdrawn. In this case, they were able to reverse their previous positions painlessly because their approval of ddI on its own means that the drug will remain available to patients who are already taking it.

The FDA, however, is not obliged to accept the panel's advice. And it is likely to continue with the accelerated approval of combination therapy with AZT and $\mathrm{ddC}$ while the suppliers of the drugs complete a larger study of their efficacy.

But activists are growing increasingly concerned at the dilemmas they face. "Wo have arrived in hell," Gonsalves told last week's meeting. He can scarcely be accused of hyperbole. With no proof of efficacy for AZT, ddI or ddC, the question arises of whether new therapies and combinations should be tested against old, failed ones, or against neutral placebos. If the latter, patients and doctors must be found who are willing to forgo treatment with existing drugs in order to participate in the trials.

Colin Macilwain
France plans to raise science budget - or does it?

Paris. France's new conservative government plans to reduce the rate at which spending on science had been rising under its socialist predecessor. But, according to its budget for next year released in Paris last week, research funding will still rise faster next year than the planned 1.1 per cent

\section{IMAGE UNAVAILABLE FOR COPYRIGHT REASONS}

\section{François Fillon: promising more money.}

overall growth in public spending. Particular increases will be targeted on medical science and industrial research.

French scientists are still trying to work out exactly how much better off they are going to be. François Fillon, the minister for higher education and research, says his proposed budget of FF51.6 billion (US\$9.3 billion) is 3.8 per cent higher than this year.

But Fillon was making the comparison with the revised budget for 1993. If the proposed 1994 budget is compared to the government's original request, the increase drops to less than 2 per cent. Fillon says that this comparison is invalid, however, because the former Socialist government proposed the original 1993 budget on the basis of "false growth projections".

To complicate matters further, Fillon's comparison is based on combining the costs of research overheads and actual cash payments; previous calculations on the size of the science budget were based on combining overheads and programme authorizations. If conventional comparisons are made, the proposed 1994 budget is only 1.2 per cent higher than the revised 1993 budget, and 2 per cent less than the original.

Even using Fillon's figures, however, French research organizations will have to live next year with budget increases only slightly higher than the anticipated 2.2 per cent rate of inflation. The budget of the Centre National de la Recherche Scientifique (CNRS) will grow by 2.8 per cent to FF 12.4 billion; that of the medical research agency INSERM by 2.4 per cent to FF2.3 billion; and the agricultural research organization INRA by 2.2 per cent to FF3.1 billion.

In contrast, the French space agency CNES and the marine research agency IFREMER received proposed increases of 7.1 per cent (to FF8.7 billion) and 3.7 per cent (to FF0.93 billion).

Declan Butler 